Swarthmore College

Works

4-1-2014

\title{
Symbiosis As The Way Of Eukaryotic Life: The Dependent Co- Origination Of The Body
}

Scott F. Gilbert

Swarthmore College, sgilber1@swarthmore.edu

Follow this and additional works at: https://works.swarthmore.edu/fac-biology

Part of the Biology Commons

Let us know how access to these works benefits you

\section{Recommended Citation}

Scott F. Gilbert. (2014). "Symbiosis As The Way Of Eukaryotic Life: The Dependent Co-Origination Of The Body". Journal Of Biosciences. Volume 39, Issue 2. 201-209. DOI: 10.1007/s12038-013-9343-6 https://works.swarthmore.edu/fac-biology/194

This work is brought to you for free by Swarthmore College Libraries' Works. It has been accepted for inclusion in Biology Faculty Works by an authorized administrator of Works. For more information, please contact myworks@swarthmore.edu. 


\title{
Symbiosis as the way of eukaryotic life: The dependent co-origination of the body
}

\author{
SCOTT F GILBERT \\ Department of Biology, Swarthmore College, Swarthmore, Pennsylvania 19081, USA \\ and \\ Biotechnology Institute, University of Helsinki, 00014 Helsinki, Finland \\ (Email,sgilber1@swarthmore.edu)
}

\begin{abstract}
Molecular analyses of symbiotic relationships are challenging our biological definitions of individuality and supplanting them with a new notion of normal part-whole relationships. This new notion is that of a 'holobiont', a consortium of organisms that becomes a functionally integrated 'whole'. This holobiont includes the zoological organism (the 'animal') as well as its persistent microbial symbionts. This new individuality is seen on anatomical and physiological levels, where a diversity of symbionts form a new 'organ system' within the zoological organism and become integrated into its metabolism and development. Moreover, as in normal development, there are reciprocal interactions between the 'host' organism and its symbionts that alter gene expression in both sets of cells. The immune system, instead of being seen as functioning solely to keep microbes out of the body, is also found to develop, in part, in dialogue with symbionts. Moreover, the immune system is actively involved in the colonization of the zoological organism, functioning as a mechanism for integrating microbes into the animal-cell community. Symbionts have also been found to constitute a second mode of genetic inheritance, providing selectable genetic variation for natural selection. We develop, grow and evolve as multi-genomic consortia/teams/ecosystems.
\end{abstract}

[Gilbert SF 2014 Symbiosis as the way of eukaryotic life: The dependent co-origination of the body. J. Biosci. 39 201-209] DOI 10.1007/s12038-0139343-6

\section{Perceiving individuality}

We are accustomed to thinking of animals as unique individuals. However, this is a matter of perception, not analysis. For biologists, individuality has been a major problematic concern. As EB Wilson noted in 1896,

There is at present no biological question of greater moment than the means by which the individual cell-activities are coordinated, and the organic unity of the body maintained; for upon this question hangs not only the problem of the transmission of inherited characteristics, and the nature of development, but our conception of life itself.

Indeed 'our conception of life itself' is undergoing a remarkable revolution, as new technologies have enabled us to perceive not only 'entities' but also 'relationships' that would have otherwise been unnoticed. New technologies such as polymerase chain reaction (PCR), high-throughput RNA analysis, and next-generation sequencing have dramatically transformed our conceptions of the biosphere. They have revealed a microbial world of incredible complexity, and also a living world of complex and intermingled relationships - not only among microbes but also between microscopic and macroscopic life (Gordon 2012). Symbiosis is becoming one of the central principles of contemporary biology, replacing an essentialist conception of organismal 'individuality' with a new conception congruent with a larger systems biology approach. These discoveries have profoundly challenged the generally accepted view of 'individuals'.

In microbial and botanical sciences, symbiosis between a larger body and numerous smaller ones is taken as a matter of course. The acceptance of rhizobia, mycorrhizae and endocytic fungae as important components of plant life, for instance, is normative. Nonetheless, zoologists have subscribed to a more individualist conception of the organism,

Keywords. Evolution; holobiont; individuality; symbionts; symbiosis 
since the role of microbial symbionts had been more difficult to document in animal development, physiology and evolution (Sapp 1994, 2002, 2009). Zoological organisms have been defined as anatomical, embryological, physiological, immunological, genetical or evolutionary individuals (Geddes and Mitchell 1911; Clarke 2010; Nyhart and Lidgard 2011; Gilbert et al. 2012). These conceptions, though, are not wholly independent of one another, and each of these definitions stems from the common tenet of genomic individuality: an individual comprises a single genome.

New data have revealed that animals are composites of many species living, developing and evolving together (Gilbert et al. 2012; McFall-Ngai et al. 2013). This discovery that symbiosis is the rule and not the exception in the animal kingdom is fundamentally transforming the classical conception of an insular individuality into one in which interactive relationships among species creates a new realm of individuality, a 'holobiont' - the integrated organism resulting from host cells and persistent populations of symbionts. This notion challenges and seeks to replace the concept of a monogenomic individual whose essential identity arises during development, is maintained by the immune system, and which is selected through evolution.

\section{Anatomical individuality}

The anatomical individual animal is regarded as a structured whole. Yet, PCR data show that animals 'share' their bodies with numerous 'species' of bacteria and other microbes. The algal symbiont, Symbiodinium, provides most of the nutrients needed by its host coral (the term 'host' is used here in the classical sense to denote the larger, eukaryotic, multicellular organism in or on which the 'symbiont' resides). When this symbiosis is broken (for instance, by a prolonged increase in sea-surface temperatures), these corals 'bleach'. That is to say, they lose their algal symbionts and die. Similarly, the entity we call a cow is an organism whose complex ecosystems of gut symbionts - diverse communities of cellulose-digesting bacteria, anaerobic fungi and ciliated protists - defines its plantdigesting physiology, and has played a determinative role in its evolution (Kamra 2005).

Mastotermes darwiniensis, a termite of northern Australia, is especially problematic in terms of individuality. The worker termites eat trees, digesting the cellulose in their guts and constructing elaborate subterranean nests. But the worker termite cannot digest cellulose without its gut symbiont, Mixotricha paradoxa, which is itself an anatomical composite of at least five other species, including a eukaryotic protest that has the nucleus, a bacterium that acts as a mitochondrion, about 250,000 Trepinoma spirochetes that provide locomotion, a large bacillus, and about 200 larger spirochetes. Margulis and Sagan (2001) aptly called it 'the beast with five genomes'.
It is estimated that nine out of every ten cells in the human body are bacterial (Bäckhed et al. 2005; Ley et al. 2006), and metagenomic sequencing (Qin et al. 2010) has shown that each human gut has entered into a persistent partnership with over 150 species of bacteria. The gene set contained by this symbiotic gut metagenome in the human species is about 150 times larger than that of the human eukaryotic genome. And this does not include the symbionts of human airways, skin, mouth, excretory or reproductive orifices.

Animals, therefore, cannot be regarded as individuals by anatomical criteria, but rather as holobionts, integrated organisms composed of both host cells and persistent populations of symbionts (Rosenberg et al. 2007).

\section{Developmental individuality}

The developmental view of animal individuality (Huxley 1852) is a variant of the anatomical version of biological individuality. Here, the individual animal is understood to be that which proceeds from ovum to ovum. This was critically important after Robert Remak and others showed that animals were composed of myriads of smaller individuals, each alive in its own right (Nyhart and Lidgard 2011). Indeed, developmental mechanics (experimental embryology) centered around the question of developmental individuality. Roux and Metchnikoff each had his own version respective version of Darwinian selection occurring within the embryo; and Driesch revolutionized embryology with his discovery that each cell of the early sea urchin embryo could produce a complete individual larva. How could a part become a whole? Spemann began his embryological studies with the observation that a partially constricted newt egg could give rise to a 'partially split individuality', having two 'egotisms' derived from a single egg. Somehow, the potentially independent and competitive parts of the embryo were normally integrated to form a singular individual whole (Hamburger 1988; Gilbert 1992). ${ }^{1}$

This notion of a dynamic part-whole relationship is being extended to symbionts as part of the development of the body. New evidence demonstrates that what we understand to be the 'individual' develops as consortia of animal cells and microbes (McFall-Ngai 2002; Gilbert and Epel 2009; Fraune and Bosch 2010; Pradeu 2011). Indeed, the development of both vertebrates and invertebrates (especially larval and postembryonic development) is predicated on intimate relations with microbes.

\footnotetext{
${ }^{1}$ Even today, this ability of the whole to regulate its parts and to make the parts 'fit' is revelatory. Even some aggressive adult cancer cells, defined by their being 'autonomous', can become normally functioning parts of the body when placed into a particular portion of the embryo (Stewart and Mintz 1981; Kasemeier-Kulesa et al. 2008).
} 
For instance, in numerous organisms, the development of particular organs depends on chemical signals from symbionts (Douglas 1988, 2010). The ovaries of the parasitoid wasp, Asobara, require signals from their Wolbachia symbionts if they are not to undergo apoptosis (Pannebakker et al. 2007). Newborns of the squid Euprymna scolopes lack a light organ. The instructions for making this organ are not encoded in the genome of the squid; rather, the squid embryo has evolved the ability to cooperate with one particular bacterial species, Vibrio fischeri (McFall-Ngai et al. 2012). Without this bacteria, the light organ does not develop. Without the squid, the luminescent genes of the bacteria are not expressed.

In mammals, the development of the immune and digestive systems is not completed without gut bacteria (Ley et al. 2006, 2008; Lee and Mazmanian 2010). 'Germ-free' (asymbiotic) mice have insufficient intestinal capillaries, poorly developed or absent gut-associated lymphoid tissue, and a T-cell repertoire so diminished that they have an immunodeficiency syndrome (Stappenbeck et al. 2002; Rhee et al. 2004; Niess et al. 2008; Duan et al. 2010). In zebrafish, microbes act through the canonical Wnt pathway to regulate the normal proliferation of the intestinal stem cells (Rawls et al. 2004; Bates et al. 2006). In both species, normal differentiation and growth of the gut depends on symbiotic microbes.

One particularly interesting area of microbial effects on holobiont development involves mammalian brain formation. Germ-free mice, for example, have lower levels of NGF-1A and BDNF (a transcription factor and a paracrine factor associated with neuronal plasticity) in relevant portions of their brains than do conventionally raised mice. Heijtz et al. (2011) concluded that 'during evolution, the colonization of gut microbiota has become integrated into the programming of brain development, affecting motor control and anxiety-like behavior'. Other investigators have noticed similar effects and have concluded that a 'microbe-gut-brain' axis exists (Rhee et al. 2009; Cryan and O'Mahony 2011; Collins et al. 2012; Cryan and Dinan 2012).

The relationship between symbiotic bacteria and the development of various cognitive states is now being explored (McLean et al. 2012; Mulle et al. 2013). The ingestion of certain Lactobacillus strains, for instance, lowers stress-induced corticosterone levels in mice and alters their behaviour. The behavioural effects correlated with the ability of this bacterial strain to increase the levels of the mRNA for a major GABA receptor subunit in the prefrontal cortex. Moreover, the effects of the bacteria can be abrogated by severing the region of the vagus nerve connecting the gut to the brain (Bravo et al. 2011). The ability of new gut microbes to help alleviate the anoxia of kwashiorkor similarly opens up an entire area of research (Smith et al. 2013).

Unlike insects, which can receive their microbial symbionts through the female germ cells, mammals acquire theirs by infection. As soon as the amnion breaks or when infants suckle or cuddle, microbes colonize the guts. Moreover, just as in traditional embryonic development, the microbes produce chemicals that induce appropriate gene expression in the neighbouring cells. In the developing guts of mice and zebrafish, hundreds of genes are activated by bacterial symbionts (Hooper et al. 2001; Rawls et al. 2004). In mice, the 'normal' levels of angiogenin-4 and colipase gene expression are those levels induced by the bacteria. The co-evolution of mammals and their gut bacteria has in effect resulted in the 'outsourcing' of developmental signals from animal cells to microbial symbionts. Mother's milk even contains sugars that the mammal cannot digest but which serve as food sources for the symbionts (Zivkovic et al. 2011). The symbionts are thus integrated into the normal networks of animal development, interacting with the eukaryotic cells of their 'host', and development is a matter of interspecies communication (Gilbert 2001, 2003; McFall-Ngai 2002). Development is a matter of interspecies communication. We not only co-evolve; we codevelop, and from the viewpoint of developmental biology we are not individuals.

\section{Physiological individuality}

The physiological view of animal individuality regards the organism as composed of parts that cooperate for the good of the whole (Milne-Edwards 1827; Leuckart 1851). The complexity of animal organization is seen to be accompanied by the increasing division of labour among organ systems, a concept analogous to Adam Smith's conception that socioeconomic progress in complex societies results from the division of labour (Limoges 1994).

Molecular research has now demonstrated that symbionts can become part of an obligatorily integrated union (MacDonald et al. 2011; Vogel and Moran 2011). For example, the 'genome' of the mealy bug Planococcus is the product of a nested symbiosis: animal cells harbour the betaproteobacterium Tremblaya princeps, which in turn harbour a gammaproteobacterium, provisionally named Moranella endobia. The synthesis of amino acids appears to be coordinated between these two microbes and the host. Three of the enzymes needed for phenylalanine biosynthesis are encoded by the Moranella bacterium, five other enzymes are encoded by the Tremblya bacterium, and a final enzyme in this pathway is encoded by the genome of the insect itself (McCutcheon and von Dohlen 2011). Note that the genomes of all three organisms have been altered through this symbiosis. Such metagenomic sequencing has demonstrated the importance of microbes in insect physiological systems (Vásquez et al. 2012; Weiss et al. 2012).

Integrated host-symbiont biochemical pathways is characteristic of mammals as well; and a new concept, cometabolism, 
has been introduced to describe the physiology of the holobiont (Smith et al. 2013). This notion reflects the findings that about one-third of a mammal's metabolome (the diversity of molecules carried in its blood) has a microbial origin (Wikoff et al. 2009; McFall-Ngai et al. 2013). The term was introduced to describe the findings that kwashiorkor was not just a disease of protein-poor diet. Rather, the disease originated through poor diet plus certain types of bacteria. The gut bacteria take our ingested foods and convert them into new products. What a person's cells experience is the result of cometabolism, 'a function of microbiota and host diet'.

Microbial symbiosis also has been demonstrated in vertebrate physiology. Specific bacteria induce the formation of regulatory T-lymphocytes that suppress potentially dangerous immune responses that can cause inflammatory bowel disease (Mazmanian et al. 2008; Chow et al. 2010). The role of symbiotic microbes in mammalian disease prevention is well recognized today (Mazmanian et al. 2008; Lee and Mazmanian 2010; Ballal et al. 2011), and different bacterial strains may alter how calories are obtained and may predispose mammals to weight gain and fat tissue formation (Ley et al. 2005; Turnbaugh and Gordon 2009; Everard et al. 2013). Indeed, bacteria may be critical in maintaining a woman's health during the last stages of pregnancy. When bacteria from pregnant women in their third trimester were transplanted into germ-free mice, the mice became fatter and developed insulin resistance, just as pregnant women do. This did not happen with the bacteria from first-trimester pregnant women (Koren et al. 2012). Microbial symbionts appear to be a normal part of animal physiology, working toward a functional holobiont. We are not individuals by physiological criteria.

\section{Genetic individuality}

Microbial symbionts form a second type of genetic inheritance (Moran 2007; Gilbert 2011). Arthropods often acquire their symbionts vertically though the maternal germline as well as horizontally from the environment, while mammals usually obtain them from the maternal reproductive tract and from the interactions following birth. In aphids, symbiotic bacteria provide selectable allelic variation (such as thermotolerance, colour and parasitoid resistance) that enable some holobionts to persist better under different environmental conditions (Dunbar et al. 2007; Tsuchida et al. 2010). Thus, whether the holobiont can reproduce in hot weather, have cryptic coloration or survive a parisitoid wasp infection depends not on 'its' genome but on the genome of its symbionts. There is also allelic variation in the human microbiome. The genes of Bacteroides plebeius differ in different human populations. The Japanese strain contains at least two genes (horizontally transferred from a marine relative) that enable the bacteria to metabolize complex sugars, such as those found in seaweeds (Hehemann et al. 2010, 2012). Indeed, the Human Microbiome Project (Turnbaugh et al. 2007) has applied ecological metagenomics to explore the microbial world within the human species.

In some species, the symbiont will actually bias its transmission. The common arthropod symbiont, Wolbachia, is only transmitted through the female germline (i.e. by the oocyte.) Males do not transmit these bacteria. In Amadillidium (the pillbug), Wolbachia will override the host's genetic mechanisms of sex determination, changing the development of the organism from male to female (Cordaux et al. 2004).

Symbionts can give us selectable genetic variation and comprise a second path of genetic inheritance. Our bodies have multiple genotypes.

\section{Immunological individuality}

The discipline of immunology has been called 'the science of self/non-self discrimination' (Klein 1982). In this view, the immune system consists of defensive 'weaponry', evolved to protect the body against threats from pathogenic microbes. Accordingly, if it were not for the immune system, opportunistic infections would prevail (as they do in cases of immune deficiencies), and the organism would perish.

In a fascinating inversion of this view of life, recent studies have shown that an individual's immune system is in part created by the newly acquired microbiome. In vertebrates, the gut-associated lymphoid tissue is specified and organized by bacterial symbionts (Rhee et al. 2004; Lanning et al. 2005). When symbiotic microbes are absent in the gut, the immune system fails to function properly and its repertoire is significantly reduced (Lee and Mazmanian 2010; Round et al. 2010). Similarly, Hill et al. (2012) have shown that microbial symbionts provide developmental signals that limit the proliferation of basophil progenitor cells and thereby prevent basophil-induced allergic responses. Lee and Mazmanian (2010) conclude, 'multiple populations of intestinal immune cells require the microbiota for their development and function'.

The immune system, therefore, appears to be more of a 'passport control agent' or even a 'bouncer' rather than a defensive army posted to keep the zoological organism 'pure'. It distinguishes, by evolutionary experience, between potential symbionts and the potential pathogens (Matzinger 1994). Indeed, the immune system actively recruits the symbionts. Peterson et al. (2007) have shown that intestinal IgA, in addition to its well-known role in attacking pathogens, plays a 'critical role in establishing a sustainable host-microbial relationship'. Similarly, these Peyer's patch antibodies, which are essential in fighting opportunistic pathogens, appear to be 
involved in 'the creation of an optimal symbiotic environment on the interior of the PPs' (Obata et al. 2010). Even the Tolllike receptors that mediate innate immunity are utilized by Bacteroides to establish a host-commensal relationship. The ability of symbiotic bacteria to use the innate and acquired immunity pathways to initiate symbioses has led Round et al. (2011, p 974) to conclude that 'the immune system can discriminate between pathogens and the microbiota through recognition of symbiotic bacterial molecules in a process that engenders commensal colonization'. In squids (McFall-Ngai et al. 2010) and mammals (Hooper et al. 2012), elements of the host immune system have been co-opted to support the colonization, limitation and persistence of symbiotic bacteria within the host.

Thus, the immune system, built, in part, under the supervision of microbes, does not merely guard the body against other hostile organisms in the environment but it also mediates the body's participation in a community of 'others' that contribute to its welfare (Tauber 2000, 2008; Agrawal 2001; Hooper et al. 2001; Dale and Moran 2006). What counts as an individual is now seen as being dynamic, contextdependent and responsive to symbionts.

\section{Evolutionary individuality: The revised individual}

Biological individuality has also been defined evolutionarily, as that which can be selected. The individuals are usually considered to be genes or monogenomic organisms. But, from the above discussion, it is evident that organisms are anatomically, physiologically, developmentally, genetically and immunologically multigenomic and multispecies complexes. Can it be that organisms are selected as multigenomic associations? Is the fittest in life's struggle the multispecies consortium, and not an individual of a single species in that group? This possibility has been raised by Bateson (1988), who argued that 'the outcome of the joint action of individuals could become a character in its own right'.

An instructive example comes from studies of the pea aphid, Acyrthosiphon pisum, and the several species of bacteria that live within its cells. Variants of Buchnera spp. bacteria provide the aphid with thermotolerance (at the expense of fecundity at normal temperatures; Dunbar et al. 2007); Rickettsiella bacteria provides a pathway for aphid colour change, turning genetically red aphids green through the synthesis of quinones (Tsuchida et al. 2010); and some variants of the bacteria Hamiltonella spp. provide immunity against parasitoid wasp infection (Oliver et al. 2009). However, in the last case, the protective variants of Hamiltonella result from the incorporation of a specific lysogenic bacteriophage within the bacterial genome. The aphid must be infected with Hamiltonella, and the Hamiltonella must be infected by phage APSE-3. As Oliver et al. (2009, p 994) write, 'In our system, the evolutionary interests of phages, bacterial symbionts, and aphids are all aligned against the parasitoid that threatens them all. The phage is implicated in conferring protection to the aphid and thus contributes to the spread and maintenance of $H$. defensa in natural $A$. pisum populations'. But there is a trade-off to the host in having this beneficial protection. In the absence of parasitoid infection, those aphids carrying the bacteria with lysogenic phage are not as fecund as those lacking this phage. A similar trade-off occurs in aphids that carry the thermotolerant alleles of Buchnera. Those aphids whose symbionts bear the heat-resistant allele have less fecundity at milder temperatures than their sisters whose bacteria lack the functional allele for the heat-shock protein. However, the population as a whole can survive hot weather, which would otherwise prevent reproduction. As Bateson (1988) had pointed out, it is the whole that gets selected, and that 'focusing on the genetics of individuals muddles the issue of what is necessary for differential survival with what is required for replication'.

But if animals are not genetic or anatomical individuals, and if there is no 'individual organism', what remains of classic notions of 'individual selection'? This moves the biological discussion of symbiotic associations into the arena of 'group selection'. Most discussions of group selection, however, are not germane here, because they assume that the group in question is composed of members of a single species. However, one important concern is relevant to our discussion of the holobiont: cheaters. The major problem for all group selection theories (and the groups themselves) are potential 'cheaters', those lower-level parts of the group that would proclaim their own autonomy and that would multiply at the expense of the others. The problem of 'cheaters' then has to be solved in such a way that associates in a symbiotic relationship are under the social control of the whole, the holobiont (Stearns 2007).

This strong socializing and unifying force is found in the immune system, and here we find a solution to the problem of cheaters in a symbiotic complex. As mentioned earlier, the immune system must now be formulated as having two 'limbs': an outward-looking limb that defines the organism as that which is to be protected from foreign pathogens, and an inward-looking arm that looks for potential dangers arising from within the organism itself (Burnet and Fenner 1949; Tauber 2000, 2009; Ulvestad 2007; Eberl 2010; Pradeu 2010). This dualistic vision was the original conception of Metchnikoff at the end of the 19th century (Tauber 1994). If the immune system serves as the integrating system, keeping the animal and microbial cells together, then to obey the immune system is to become a citizen of the holobiont. To escape immune control is to become a pathogen or a cancer. Cheaters are destroyed by the immune system.

Thus, the symbionts are welcomed into the animal body and are regulated by the immune system. As part of the 
body, the microbes not only help the body develop and remain physiologically intact, they also provide a secondary system of genetic transmission from parent to offspring. They can provide selectable variation from generation to generation. Moreover, in addition to providing this selectable variation, microbial symbionts may have played, and continue to play, other roles in animal evolution as well (Margulis and Fester 1991). Animal speciation may be mediated, in part, through the ability of microbes to induce reproductive isolation. This can be achieved through symbiontinduced cytoplasmic incompatibility between hybrids (Bruckner and Bordenstein 2012) or by symbiont-induced mate selection (Sharon et al. 2010). In many arthropods, those animals infected with one strain of Wolbachia cannot mate with members infected with a different strain. Wolbachia appears to be producing a reproductive barrier separating species into two groups. In the wasp Nasonia, Wolbachiainduced cytoplasmic incompatability appears to be the event that split a group of such wasps into Nasonia giraulti and Nasonia longicornis (Bordenstein et al. 2001). Here, the wasps can interbreed if the symbionts are removed; but the hybrids between them die if the symbionts are present.

Reproductive isolation can also be achieved by influencing mate selection. This appears to be the case in Drosophila, where mate selection has been shown to be dependent on symbionts that are introduced into the fly larvae through its food. If the symbionts are removed, the mating preference is abrogated (Sharon et al. 2010). In both these cases, symbionts effect reproductive isolation, a critical sine qua non of speciation.

Last, we may never have been 'pure' animals, innocent of symbionts. We must remember that eukaryotic protists were not only created by endosymbiosis, but that the protist world is full of complex symbioses (Margulis 1981; Margulis and Fester 1991; Sapp 2009). Some of these microbial symbioses may have led to multicellularity. The choanoflagellates are unicellular protists that are the sister group of the animals. However, these unicellular forms can be converted into multicellular entities - complete with an extracellular matrix and cytoplasmic bridges between cells - by a specific bacterium that often coexists with them. If the protists are cultivated in filtered water, they remain unicellular. If the bacteria are added back, they can form multicellular entities (Dayel et al. 2011; Alegado et al. 2012). Thus, bacteria symbionts may have been important in initiating multicellularity, the ultimate part/whole dialectic in biology.

Animals, then, can no longer be considered individuals in any sense of classical biology: anatomical, developmental, physiological, immunological, genetic or evolutionary. Our bodies must be understood as holobionts whose anatomical, physiological, immunological and developmental functions evolved in shared relationships of different species (ZilberRosenberg and Rosenberg 2008). Thus, the holobiont, with its integrated community of species, becomes a unit of natural selection whose evolutionary mechanisms are largely unexplored (Savinov 2011). Indeed, if the incorporation of new participants, with novel genetic and physiological properties, into evolving holobionts has been a common evolutionary strategy, some major tenets of the Modern Synthesis may need re-evaluation. As Lewis Thomas (1974, p142) commented when considering self and symbiosis: 'This is, when you think about it, really amazing. The whole dear notion of one's own Self - marvelous, old free-willed, free-enterprising, autonomous, independent island of a Self - is a myth'. Our new biology will have to deal with this.

\section{Acknowledgements}

I wish to thank Dr V Nanjundiah for organizing this workshop, and Drs AI Tauber and J Sapp for their encouragement and discussions. This article is based on Gilbert et al. 2012.

\section{References}

Agrawal AA 2001 Phenotypic plasticity in the interactions and evolution of species. Science 294 321-326

Alegado RA, Brown LW, Cao S, Dermenjian RK, Zuzow R, Fairclough SR, Clardy J and King N 2012 A bacterial sulfonolipid triggers multicellular development in the closest living relatives of animals. eLife $\mathbf{1}$ e00013

Ballal SA, Gallini CA, Segata N, Huttenhower C and Garrett WS 2011 Host and gut microbiota symbiotic factors: lessons from inflammatory bowel disease and successful symbionts. Cell. Microbiol. 13 508-517

Bates JM, Mittge E, Kuhlman J, Baden KN, Cheesman SE and Guilemin K 2006 Distinct signals from the microbiota promote different aspects of zebrafish gut differentiation. Dev. Biol. 297 374-386

Bateson P 1988 The biological evolution of cooperation and trust; in Trust: Making and breaking cooperative relations (ed) D Gambetta (Oxford: Blackwell) pp 14-30

Bäckhed F, Ley RE, Sonnenbury JL, Peterson DA and Gordon JI 2005 Host-bacterial mutualism in the human intestine. Science 307 1915-1920

Bordenstein SR, O'Hara FP and Werren JH 2001 Wolbachiainduced incompatibility precedes other hybrid incompatibilities in Nasonia. Nature 409 707-710

Bravo JA, Forsythe P, Chew MV, Escaravage E, Savignac HM, Dinan TG, Bienenstock J and Cryan JF 2011 Ingestion of Lactobacillus strain regulates emotional behavior and central GABA receptor expression in a mouse via the vagus nerve. Proc. Natl. Acad. Sci. USA 108 16050-16055

Bruckner RM and Bordenstein SR 2012 Speciation by symbiosis. Trends Ecol. Evol. 27 443-451

Burnet FM and Fenner F 1949 The production of antibodies 2nd edition (Melbourne: Macmillan and Company)

Chow J, Lee SM, Shen Y, Khosravi A and Mazmanian SK 2010 Host bacterial symbiosis in health and disease. Adv. Immunol. $107243-274$ 
Clarke E 2010 The problem of biological individuality. Biol. Theory 5 312-325

Collins SM, Surette M and Bercik P 2012 The interplay between the intestinal microbiota and the brain. Nat. Rev. Microbiol. 10 735-742

Cordaux R, Michel-Salzat A, Frelon-Raimond M, Rigaud T and Bouchon D 2004 Evidence for a new feminizing Wolbachia strain in the isopod Armadillidium vulgare: evolutionary implications. Heredity 93 78-84

Cryan JF and Dinan TG 2012 Mind-altering microorganisms: the impact of the gut microbiota on brain and behaviour. Nat. Rev. Neurosci. 13 701-712

Cryan JF and O'Mahony SM 2011 The microbiome-gut-brain axis: from bowel to behavior. Neurogastroenterol. Motility 23 187-192

Dale C and Moran NA 2006 Molecular interactions between bacterial symbionts and their hosts. Cell 126 453-465

Dayel MJ, Alegado RA, Fairclough SR, Levin TC, Nichols SA, McDonald K and King N 2011 Cell differentiation and morphogenesis in the colony-forming choanoflagellate Salpingoeca rosetta. Dev. Biol. 357 73-82

Douglas AE 1988 Experimental studies on the mycetome symbiosis in the leafhopper Euscelis incisus. J. Insect Physiol. 34 1043-1053

Douglas AE 2010 The symbiotic habit (Princeton: Princeton University Press)

Duan J, Chung H, Troy E and Kasper DL 2010 Microbial colonization drives expansion of IL-1 receptor 1-expressing and IL-17producing $\gamma / \delta$ T cells. Cell Host Microbe 7 140-150

Dunbar HE, Wilson AC C, Ferguson NR and Moran NA 2007 Aphid thermal tolerance is governed by a point mutation in bacterial symbionts. PLoS Biol. 5 e96

Eberl G 2010 A new vision of immunity: homeostasis of the superorganism. Mucosal Immunol. 3 450-460

Everard A, Belzer C, Geurts L, Ouwerkerk JP, Druart C, Bindels LB, Guiot Y, Derrien M, et al. 2013 Cross-talk between Akkermansia muciniphila and intestinal epithelium controls diet-induced obesity. Proc. Natl. Acad. Sci. USA $1109066-9071$

Fraune S and Bosch TCG 2010 Why bacteria matter in animal development and evolution. Bioessays 32 571-580

Geddes P and Mitchell PC 1911 Morphology; in Encyclopedia Britannica 11th edition (Cambridge, UK: Cambridge University Press) pp 863-869

Gilbert SF 1992 Cells in search of community: Critiques of Weismannism and selectable units in ontogeny. Biol. Phil. 7 473-487

Gilbert SF 2001 Ecological developmental biology: developmental biology meets the real world. Dev. Biol. 233 1-12

Gilbert SF 2003 The genome in its ecological context: philosophical perspectives on interspecies epigenesis. Ann. NY Acad. Sci. $981202-218$

Gilbert SF 2011 Symbionts as genetic sources of hereditable variation; in Transformations of Lamarckism: From subtle fluids to molecular biology (eds) SB Gissis and E Jablonka (Cambridge, MA: MIT Press) pp 283-293

Gilbert SF and Epel D 2009 Ecological developmental biology: Integrating epigenetics, medicine, and evolution (Sunderland: Sinauer Associates)

Gilbert SF, Sapp J and Tauber AI 2012 A symbiotic view of life: We have never been individuals. Quart. Rev. Biol. 87 325-341
Gordon JI 2012 Honor thy gut symbionts redux. Science 3361251 1253

Hamburger V 1988 The heritage of experimental embryology (New York: Oxford University Press)

Hehemann J-H, Correc G, Barbeyron T, Helbert W, Czjzek M and Michel G 2010 Transfer of carbohydrate-active enzymes from marine bacteria to Japanese gut microbiota. Nature 464 908-912

Hehemann JH, Kelly AG, Pudlo NA, Martens EC and Boraston AB 2012 Bacteria of the human gut microbiome catabolize red seaweed glycans with carbohydrate-active enzyme updates from extrinsic microbes. Proc. Natl. Acad. Sci. USA 109 19786-19791

Heijtz RD, Wang S, Anuar F, Qian Y, Björkholm B, Samuelsson A, Hibberd ML, Forssberg H and Pettersson S 2011 Normal gut microbiota modulates brain development and behavior. Proc. Natl. Acad. Sci. USA 108 3047-3052

Hill DA, Siracusa MC, Abt MC, Kim BS, Kobuley D, Kubo M, Kambayashi T, LaRosa DF, et al. 2012 Commensal bacteriaderived signals regulate basophil hematopoiesis and allergic inflammation. Nat. Med. 18 538-546

Hooper LV, Wong MH, Thelin A, Hansson L, Falk PG and Gordon JI 2001 Molecular analysis of commensal host-microbial relationships in the intestine. Science 291 881-884

Hooper LV, Littman DR and Macpherson AJ 2012 Interactions between the microbiota and the immune system. Science 336 $1268-1273$

Huxley TH 1852 Upon animal individuality. Edinburgh New Philos. J. 53 172-177

Kamra DN 2005 Rumen microbial ecosystem. Curr. Sci. 89 124-135

Kasemeier-Kulesa JC, Teddy JM, Postovit LM, Seftor EA, Seftor RE, Hendrix MJ and Kulesa PM 2008 Reprogramming multipotent tumor cells with the embryonic neural crest microenvironment. Dev. Dyn. 237 2657-2666

Klein J 1982 Immunology: The science of self-nonself discrimination (New York: John Wiley \& Sons)

Koren O, Goodrich JK, Cullender TC, Spor A, Laitinen K, Bäckhed HK, Gonzalez A, Werner JJ, et al. 2012 Host remodeling of the gut microbiome and metabolic changes during pregnancy. Cell $150470-480$

Lanning DK, Rhee K-J and Knight KL 2005 Intestinal bacteria and development of the B-lymphocyte repertoire. Trends Immunol. 26 419-425

Lee YK and Mazmanian SK 2010 Has the microbiota played a critical role in the evolution of the adaptive immune system? Science 330 1768-1773

Leuckart R 1851 Über den Polymorphismus der Individuen oder die Erscheinungen der Arbeitsteilung in der Natur. Ein Beitrag zur Lehre vom Generationswechsel (Giessen, Germany: Ricker)

Ley RE, Bäckhed F, Turnbaugh P, Lozupone CA, Knight RD and Gordon JI 2005 Obesity alters gut microbial ecology. Proc. Nat. Acad. Sci. USA 112 11070-11075

Ley, RE, Peterson DA and Gordon JI 2006 Ecological and evolutionary forces shaping microbial diversity in the human intestine. Cell $124837-848$

Ley RE, Hamady M, Lozupone C, Turnbaugh PJ, Ramey RR, Bircher JS, Schlegel ML, Tucker TA, et al. 2008 Evolution of mammals and their gut microbes. Science 320 1647-1651

Limoges C 1994 Milne-Edwards, Darwin, Durkheim and Division of Labour: A case study in reciprocal conceptual exchanges 
between the social and the natural sciences; in The natural sciences and social sciences: Some critical and historical perspectives (ed) IB Cohen (Dordrecht: Kluwer Academic Publishers) pp 317-343

MacDonald SJ, Thomas GH and Douglas AE 2011 Genetic and metabolic determinants of nutritional phenotype in an insectbacterial symbiosis. Mol. Ecol. 20 2073-2084

Margulis L 1981 Symbiosis in cell evolution: Life and its environment on the early earth (New York: WH Freeman)

Margulis L and Fester R 1991 Symbiosis as a source of evolutionary innovation (Cambridge, MA: MIT Press)

Margulis L and Sagan D 2001 The beast with five genomes. Nat. Hist. 11038

Matzinger P 1994 Tolerance, danger, and the extended family. Ann. Rev. Immunol. 12 991-1045

Mazmanian SK, Round JL and Kasper DL 2008 A microbial symbiosis factor prevents intestinal inflammatory disease. $\mathrm{Na}$ ture $\mathbf{4 5 3}$ 620-625

McCutcheon JP and von Dohlen CD 2011 An interdependent metabolic patchwork in the nested symbiosis of mealybugs. Curr. Biol. 21 1366-1372

McFall-Ngai MJ 2002 Unseen forces: the influences of bacteria on animal development. Dev. Biol. 242 1-14

McFall-Ngai M, Nyholm SV and Castillo MG 2010 The role of the immune system in the initiation and persistence of the Euprymna scolopes-Vibrio fischeri symbiosis. Semin. Immunol. 22 48-53

McFall-Ngai M, Heath-Heckman EA C, Gillette AA, Peyer SM and Harvie EA 2012 The secret languages of coevolved symbioses: insights from the Euprymna scolopes-Vibrio fischeri symbiosis. Semin. Immunol. 24 3-8

McFall-Ngai M, Hadfield MG, Bosch TC, Carey HV, DomazetLoso T, Douglas AE, Dubilier N, Eberl G, et al. 2013 Animals in a bacterial world, a new imperative for the life sciences. Proc. Natl. Acad. Sci. USA 110 3229-3236

McLean PG, Bergonzelli GE, Collins SM and Bercik P 2012 Targeting the microbiota-gut-brain axis to modulate behavior: which bacterial strain will translate best to humans? Proc. Natl. Acad. Sci. USA 109 E174

Milne-Edwards H 1827 Organisation; in Dictionnaire classique d'histoire naturelle (ed) JBGM Bory de Saint-Vincent (Paris: Beaudoin) pp 332-344

Moran NA 2007 Symbiosis as an adaptive process and source of phenotypic complexity. Proc. Natl. Acad. Sci. USA 104 8627-8633

Mulle JG, Sharp WG and Cubells JF 2013 The gut microbiome: a new frontier in autism research. Curr. Psychiatry Rep. 15337

Niess JH, Leithäuser F, Adler G and Reimann J 2008 Commensal gut flora drives the expansion of proinflammatory CD4 T cells in the colonic lamina propria under normal and inflammatory conditions. J. Immunol. 180 559-568

Nyhart LK and Lidgard S 2011 Individuals at the center of biology: Rudolf Leuckart's Polymorphismus der Individuen and the ongoing narrative of parts and wholes. With an annotated translation. J. Hist. Biol. 44 373-443

Obata T, Goto Y, Kunisawa J, Sato S, Sakamoto M, Setoyama H, Matsuki T, Nonaka K, et al. 2010 Indigenous opportunistic bacteria inhabit mammalian gut-associated lymphoid tissues and share a mucosal antibody-mediated symbiosis. Proc. Natl. Acad. Sci. USA 107 7419-7424
Oliver KM, Degnan PH, Hunter MS and Moran NA 2009 Bacteriophages encode factors required for protection in a symbiotic mutualism. Science 325 992-994

Pannebakker BA, Loppin B, Elemans CP H, Humblot L and Vavre F 2007 Parasitic inhibition of cell death facilitates symbiosis. Proc. Natl. Acad. Sci. USA 104 213-215

Peterson DA, McNulty NP, Guruge JL and Gordon JI 2007 IgA response to symbiotic bacteria as a mediator of gut homeostasis. Cell Host Microbe 2 328-339

Pradeu T 2010 What is an organism? An immunological answer. Hist. Philos. Life Sci. 32 247-268

Pradeu T 2011 A mixed self: the role of symbiosis in development. Biol. Theory 6 80-88

Qin J, Li R, Raes J, Arumugam M, Burgdorf KS, Manichanh C, Nielsen T, Pons N, et al. 2010 A human gut microbial gene catalogue established by metagenomic sequencing. Nature 464 59-65

Rawls JF, Samuel BS and Gordon JI 2004 Gnotobiotic zebrafish reveal evolutionarily conserved responses to the gut microbiota. Proc. Natl. Acad. Sci. USA 101 4596-4601

Rhee K-J, Sethupathi P, Driks A, Lanning DK and Knight KL 2004 Roles of commensal bacteria in development of gut-associated lymphoid tissues and preimmune antibody repertoire. $J$. Immunol. 172 1118-1124

Rhee SH, Pothoulakis C and Mayer EA 2009 Principles and clinical implications of the brain-gut-enteric microbiota axis. Nat. Rev. Gastroenterol. Hepatol. 6 306-314

Rosenberg E, Koren O, Reshef L, Efrony R and Zilber-Rosenberg I 2007 The role of microorganisms in coral health, disease and evolution. Nat. Rev. Microbiol. 5355 - 362

Round JL, O'Connell RM and Mazmanian SK 2010 Coordination of tolerogenic immune responses by the commensal microbiota. J. Autoimmunity $34 \mathrm{~J} 220-\mathrm{J} 225$

Round JL, Lee SM, Li J, Tran G, Jabri B, Chatila TA and Mazmanian SK 2011 The Toll-like receptor 2 pathway establishes colonization by a commensal of the human microbiota. Science 332 974-977

Sapp J 1994 Evolution by association: A history of symbiosis (New York: Oxford University Press)

Sapp J 2002 Paul Buchner (1886-1978) and hereditary symbiosis in insects. Int. Microbiol. 5 145-150

Sapp J 2009 The new foundations of evolution: On the tree of life (New York: Oxford University Press)

Savinov AB 2011 Autocenosis and democenosis as individual- and population-level ecologicla categories in terms of symbiogenesis and systems approach. Russian J. Ecol. 42 179-185

Sharon G, Segal D, Ringo JM, Hefetz A, Zilber-Rosenberg I and Rosenberg E 2010 Commensal bacteria play a role in mating preference of Drosophila melanogaster. Proc. Natl. Acad. Sci. USA 107 20051-20056

Smith MI, Yatsunenko T, Manary MJ, Trehan I, Mkakosya R, Cheng J, Kau AL, Rich SS, et al. 2013 Gut microbiomes of Malawian twin pairs discordant for kwashiorkor. Science 339 548-554

Stappenbeck TS, Hooper LV and Gordon JI 2002 Developmental regulation of intestinal angiogenesis by indigenous microbes via Paneth cells. Proc. Natl. Acad. Sci. USA 99 15451-15455

Stearns SC 2007 Are we stalled part way through a major evolutionary transition from individual to group? Evolution $612275-2280$ 
Stewart TA and Mintz B 1981 Successive generations of mice produced from an established culture line of euploid teratocarcinoma cells. Proc. Natl. Acad. Sci. USA 78 6314-6318

Tauber AI 1994 The immune self: Theory or metaphor? (Cambridge, UK: Cambridge University Press)

Tauber AI 2000 Moving beyond the immune self? Semin. Immunol. 12 241-248

Tauber AI 2008a. Expanding immunology: defense versus ecological perspectives. Perspec. Biol. Med. 51 270-284

Tauber AI 2009 The biological notion of self and non-self; in Stanford encyclopedia of philosophy (ed) EN Zelta (http:// plato.stanford.edu/entries/biologyself)

Thomas L 1974 The lives of a cell: Notes of a biology watcher (New York: Viking Press)

Tsuchida T, Koga R, Horikawa M, Tsunoda T, Maoka T, Matsumoto S, Simon JC and Fukatsu T 2010 Symbiotic bacterium modifies aphid body color. Science 3301102 1104

Turnbaugh PJ and Gordon JI 2009 The core gut microbiome, energy balance and obesity. J. Physiol. 587 4153-4158

Turnbaugh PJ, Ley RE, Hamady M, Fraser-Liggett CM, Knight R and Gordon JI 2007 The human microbiome project. Nature 449 804-810
Ulvestad E 2007 Defending life: The nature of host-parasite relations (Dordrecht: Springer)

Vásquez A, Forsgren E, Fries I, Paxton RJ, Flaberg E, Szekely L and Olofsson TC 2012 Symbionts as major modulators of insect health: lactic acid bacteria and honeybees. PLoS One 7 e33188

Vogel KJ and Moran NA 2011 Sources of variation in dietary requirements in an obligate nutritional symbiosis. Proc. R. Soc. B: Biol. Sci. 278 115-121

Weiss BL, Maltz M and Aksoy S 2012 Obligate symbionts activate immune system development in the tsetse fly. J. Immunol. 188 $3395-3403$

Wikoff WR, Anfora AT, Liu J, Schultz PG, Lesley SA, Peters EC and Siuzdak G 2009 Metabolomics analysis reveals large effects of gut microflora on mammalian blood metabolites. Proc. Natl. Acad. Sci. USA 106 698-703

Wilson EB 1896 The cell in development and inheritance (New York: Macmillan) p 41

Zilber-Rosenberg I and Rosenberg E 2008 Role of microorganisms in the evolution of animals and plants: the hologenome theory of evolution. FEMS Microbiol. Rev. 32 723-735

Zivkovic AM, German JB, Lebrilla CB and Mills DA 2011 Human milk glycobiome and its impact on the infant gastrointestinal microbiota. Proc. Natl. Acad. Sci. USA 108 4653-4658 